\title{
ANATOMIC AND HISTOLOGIC REVIEW OF THE CORONARY SINUS
}

\author{
REVISIÓN ANATÓMICA E HISTOLÓGICA DEL SENO CORONARIO
}

"Adrián Barceló; ** Luis M. De la Fuente \& ***:Simon H. Stertzer.

\begin{abstract}
BARCELÓ, A.; DE LA FUENTE, L. M. \& STERTZER, S. H. Anatomic and histologic rewiew of the coronary sinus. Int. J. Morphol., 22(4):331-338, 2004.
\end{abstract}

SUMMARY: The coronary sinus (CS), traditionally considered merely a great cardiac vein, is shown to display anatomic characteristics of a true cardiac chamber: endocardium, striated myocardium, epicardium and a specific conduction system.

Fourteen human hearts were dissected with optical magnification. High resolution pictures were taken with a digital camera. The data was analyzed with specialized computer software.

Macroscopic findings: 1) the existence of striated myocardial muscle forming the wall of the CS over its entire circumference, 2) muscular CS-atrial connections and, 3) an previously undescribed muscular atrio-coronary sinus bundle. Two muscular tracts linking the CS to the right atrium (RA), (one antero-superior or septal, and another postero-inferior or atrial) were discovered as well. Microscopic findings: 1) striated myocardial fibers in the media and, 2) a group of cells similar to the $\mathrm{P}$ cells of the sinus node, in addition to a large number of Purkinje-like cells. Numerous groups of ganglionic neurons were identified in the subepicardium.

In addition to its venous transport function, the CS is a discrete, cameral structure situated in the left posterior sulcus, and not intramural to the atrium or ventricle. The findings suggest that Bachmann's bundle, the atrio-coronary sinus bundle, the CS musculature and the right atrium may all be part of the conduction system, and contribute to the genesis of cardiac arrhythmias. The CS is therefore a small cardiac chamber that joins the other four chambers at the level of the crux cordis.

KEY WORDS: 1. Cardiac anatomy; 2. Coronary Sinus: 3. Arrhythmias; 4. Interatrial conduction.

\section{INTRODUCTION}

The coronary sinus (CS) has been known since the antiquity anatomists (Eristratos, $280 \mathrm{BC}$; Galeno, 129 AD) and has been considered for centuries a vein of return to the heart.

By definition, the CS is the blood conduit in the continuation of the great cardiac vein, which is situated between the valve of the great cardiac vein of Viesseun or the point of entrance of the oblique vein of Marshall and the Thebesian valve of the ostium of the CS.

From the developmental point of view, the vein of Marhall and the CS are a unit, i.e. left sinus horn and left half of the transverse portion of the embryonic sinus.
The CS is positioned rather superficially in the sulcus between left atrium and left ventricle. The constant position of the CS distinguishes it from all the other venous blood conduit, which show an extremely variable behavior.

Throughout the twentieth century several authors (Coakley et al., 1946; Keith, 1902; Liotta, 1971; von Ludinghausen et al., 1992) have notice that the structure of the CS showed myocardial fibers, meaning that striated muscle, attributing it generally to extensions or atrial connections, even some authors had describe specialized conduction cells. In another side of the study there have been a few authors that described the participation of this cells in interatrial conduction (Antz, 1998) and in the genesis of some arrhythmias (Volkmer, 2002).

* Director, Biocardioanatomy Laboratory. Instituto Universitario de Ciencias de la Salud. Fundación H. A. Barceló, Buenos Aires, Argentina.

** Professor, Interventional Cardiology, Instituto Universitario de Ciencias de la Salud. Fundación H. A. Barceló, Buenos Aires, Argentina. Professor, Interventional Cardiology. School of Medicine. Universidad del Salvador. Buenos Aires, Argentina. Instituto Argentino de Diagnóstico y Tratamiento. Buenos Aires, Argentina. The Swiss Clinic of Buenos Aires, Buenos Aires, Argentina.

**** Professor of Medicine, Division of Cardiovascular Medicine, Stanford University School of Medicine, Stanford, California, USA. 
Generally these discoveries have been extemporaneous related to the technological progress of the cardiology field and therefore they have not been rightly recognized.

The advent of the cardiac catheterism (Forssman, 1929), with the consequential possibility of obtain biopsies (Bashour, 1974), reperfusion (Gruentzig, 1981), insert electrode pacemakers (1960) or practice techniques of radiofrequency ablation (Cosio, 1991) it has offered hierarchy within the radiological field. Few image techniques, like the coronariography (Sones, 1958) has allowed to show the cyclic contraction of the CS. Just like that appear our study, been one of us (S. Stertzer, MD) trying to lean the insufficient mitral valve in experimental animals with a balloon catheter, he propose to us to do a deep microanatomy study of the CS, which we have done in our Cardioanatomy Laboratory of the Fundación H.A. Barceló (Buenos Aires, Argentina).

\section{MATERIAL AND METHOD}

Fourteen necropsied hearts from patients who died of non-cardiac disease were the substrate of this investigation. The hearts were separated from the great vessels and fixed in formalin.

Each heart was examined by dissection of coronary arteries, the cardiac valves, the atrial and ventricular myocardium, and the conduction system.

Dissection was performed with extraordinary care to protect the delicate intrinsic structure of the CS. (Figs. 1-4). High-resolution pictures were taken with a digital camera. These anatomical pictures were magnified and analyzed with specialized image edition software.

The coronary sinus lumen was sectioned along its long axis.

Histologic sections (Fig. 5) were obtained and stained with hematoxylin and eosin as well as Masson's trichrome. Special attention was given to the macroscopic and microscopic analysis of the architecture of the muscle fibers encircling the CS and their connections to the right and left atrium.

The total length of muscle surrounding the CS, its fiber orientation and its connections between CS muscle to the left and right atrium were carefully examined.

\section{RESULTS}

Macroscopic examination (Fig. 1-4): When the lumen of the CS was opened along its full length, some small crests and muscles similar to the pectinate crest and the interior of the right atrium were identified.

Although there is no definitive prior reference to this finding, the internal appearance of the CS was seen to resemble the right atrial myocardium more than to the endothelium of a vein. The external or free wall of the CS is made up of at least one thin layer of striated myocardial fibers oriented on its long axis forming a delicate net (Fig. 1-4). These fibers were usually seen to start at the level of the entrance of the oblique vein of Marshall. They envelope the CS in its circumference as a muscular cuff, extending ultimately to an opening into the right atrium. Once inside the right atrium, this muscular cuff of the CS is continuous with the fibers of the right atrium, as described below.

The postero-inferior fibers course underneath the fibers that surround the orifice of the inferior vena cava and are attenuated along the external side of the right atrium at the level of the right atrioventricular sulcus in close relationship to the inferior fibers of the crista terminalis, at the cavo-tricuspid isthmus.

The antero-superior fibers of the CS terminate in the interatrial septum, close to the atrioventricular node. These fibers appear anatomically connected to the A-V node.

The anterior surface of the CS is separated from the atrial and ventricular myocardium by connective and adipose tissue, precluding it from an intramural location in the atrioventricular sulcus, as reported by von Ludinghausen $e t$ $a l$.$) .$

This CS striated muscle cuff was present in all the specimens and it is not continuous with the atrial myocardium. There were no muscle connections between the CS musculature and the left ventricular myocardium.

Interatrial connections with the coronary sinus. Small muscular connections between the CS and the left atrial musculature, were identified along the oblique vein of Marshall. They take the form of single or double myocardial belts that encircle the terminal portion of the great cardiac vein. In addition, small muscular connections between the left atrial muscle and the anterior wall of the CS were observed at the level of the mitral ring as described by Chauvin (Chauvin et al., 2000). However, in our study, a previously undescribed striated myocardial muscle bundle 

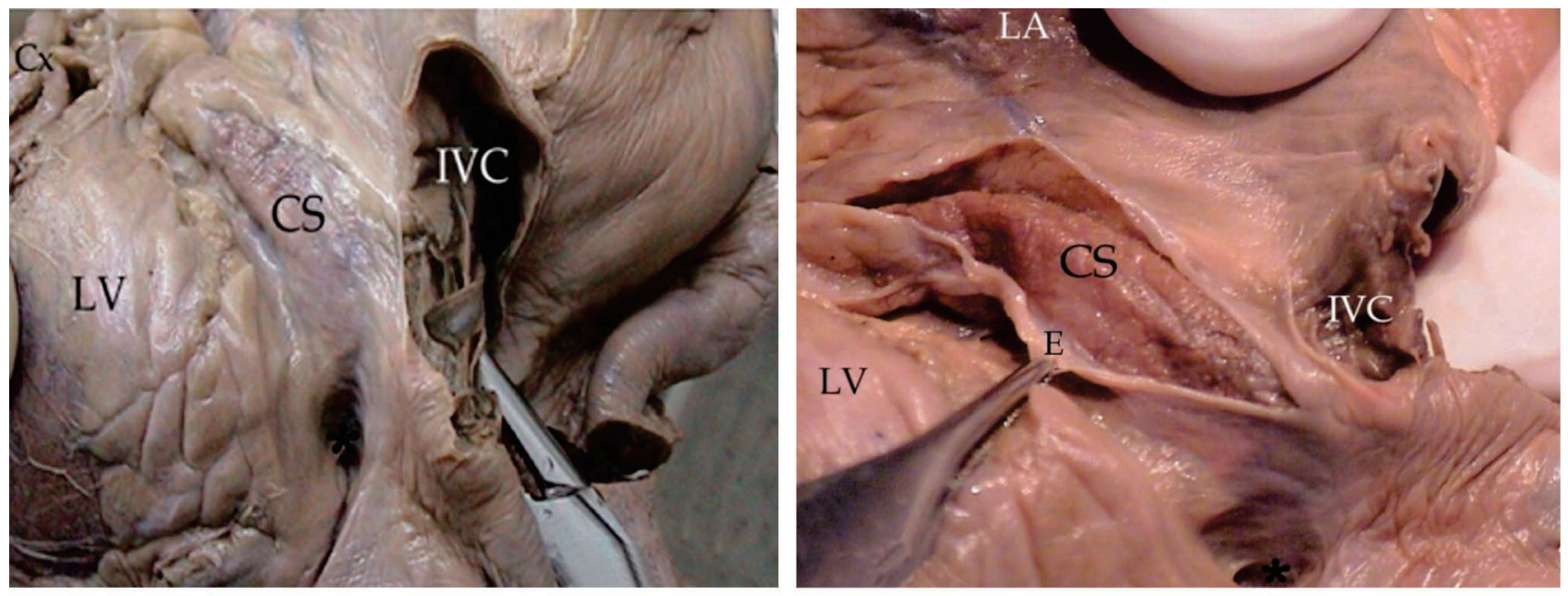

Fig. 1. Posterior view of the human heart at the crux cordis level Fig. 2. Incision and opening of the epicardial surface (E) showing (asterisk) with intact pericardium. Left ventricle (LV), coronary sinus (CS), inferior vena cava (IVC), circumflex artery (Cx).

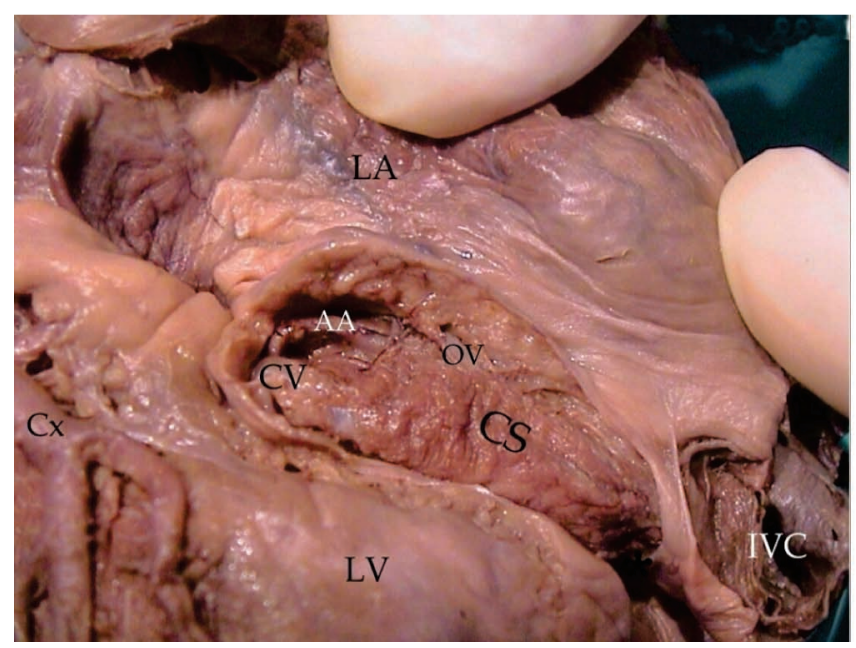
A liayer (myocardium) of the coronary sinus (CS).Left atrium (LA), left ventricle (LV), inferior vena cava (IVS) and crux cordis (asterisk).

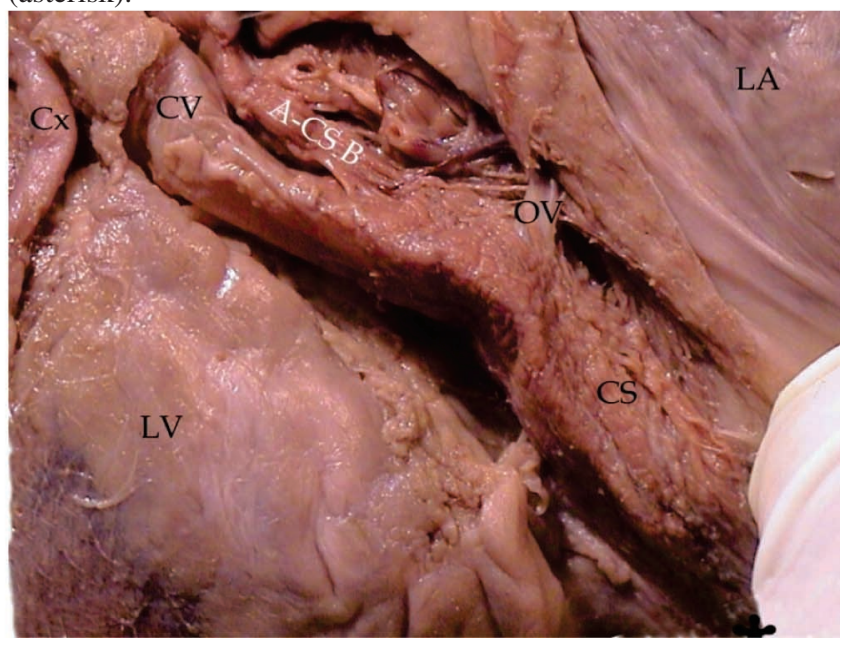

Fig. 3. Removing the soft connective and adipose tissue permits Fig. 4. After section of the posterior atrial artery, the muscular bunviewing of the oblique vein of Marshall $(\mathrm{OV})$, the great cardiac vein dle (atrio-coronary sinus bundle: A-CS B) coming from the base of (CV) with a muscular ring and the atrial posterior artery (AA). Left the atrialappendix of the left atrium (LA) is visible. Left ventricle atrium (LA), left ventricle (LV), circumflex artery (Cx), inferior vena cava (IVC), coronary sinus (CS), crux cordis (asterisk).

linking the base of the left atrial appendage to the myocardium of the CS, (at the level of the entrance of the left oblique vein of Marshall) was observed. (Fig. 4).

From the posterior aspect of the left atrium, this myocardial bundle can be seen to arise from the base of the left atrial appendage, to enter the left $\mathrm{A}-\mathrm{V}$ groove, and after a distance of approximately 30 to $40 \mathrm{~mm}$, to divide into a splay of myocardial fibers that intertwine with the fibers on the superior surface of the CS. This muscle bundle at the base of the left atrial appendage, the authors now designate as the "atrio-coronary sinus bundle", as it appears to be an extension of the anterior interatrial bundle of Bachmann $(\mathrm{LV})$, great cardiac vein $(\mathrm{CV})$, circumflex artery $(\mathrm{Cx})$. coronary sinus (CS), oblique vein of Marshall (OV).

(Bachmann, 1916). This is the first description of this muscular bundle reported to our knowledge.

Microscopic examination (Fig. 5). Selected histological sections were stained with hematoxylin and eosin, and Masson's trichrome. Immunofluorescence was utilized in some specimens.

The results indicate that the histological structure of the CS is not that of a cardiac vein.

The histology of the CS shows the three discrete layers of endocardium, myocardium and epicardium as observed in the other four cardiac chambers. 


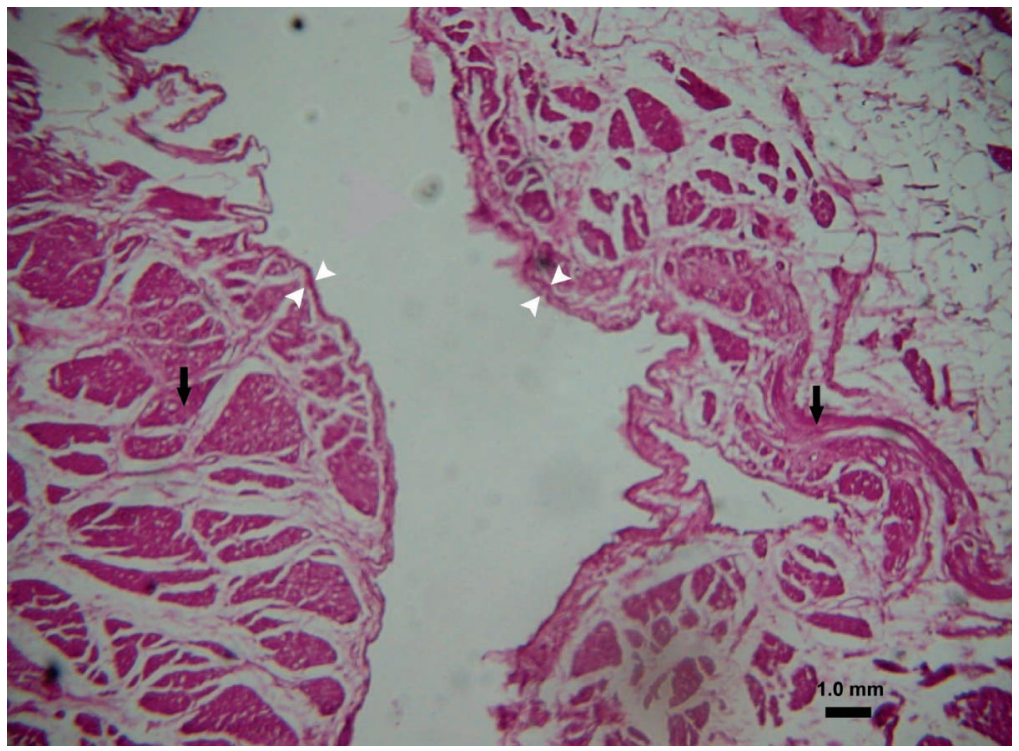

Fig. 5. The coronary sinus has been cut along its long axis. The specimen (stained with Hematoxylin and Eosin) shows the endocardium (white arrows) and the medial layer of striated myocardial muscle (black arrows).
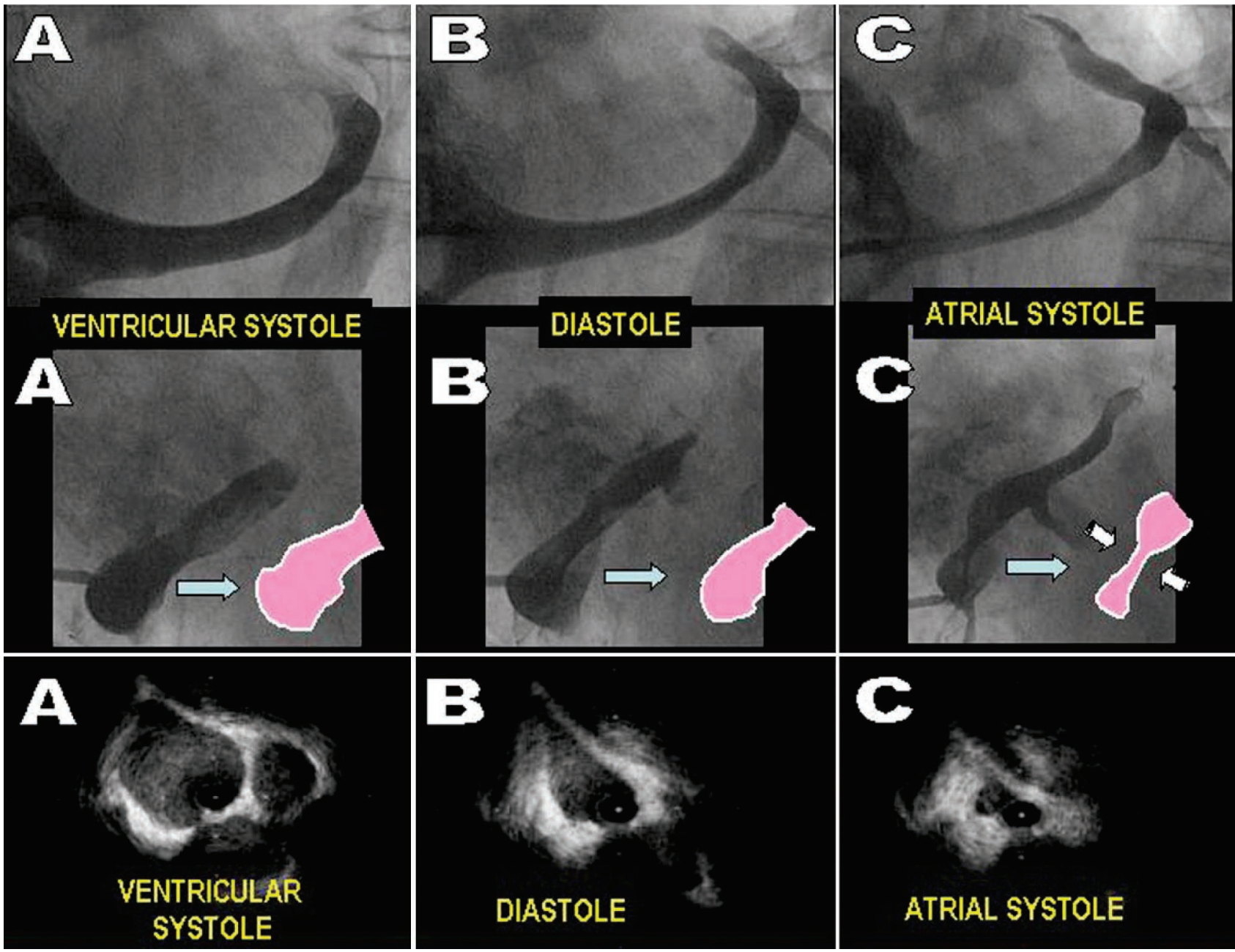

Fig. 6. Patient in normal sinus rhythm. Cine digital coronary sinus angiography. Superior row: Left anterior oblique, cycle point as indicated. Middle row: Right anterior oblique, cycle point as indicated. Lower row: Ultrasound. Maximal diameter: ventricular systole. Intermediate diameter: diastole. Minimal diameter: atrial systole. 
In the endocardium, for example, a distinct endothelium was observed, supported by a thin layer of connective tissue. (Fig. 5)

The media was formed by typically striated myocardium where the syncytium showed the characteristic cross-striation of myofibrils. The cellular appearance was indeed that of cardiac muscle, with characteristic intercalated discs.

Numerous Purkinje-like cells, with the typically clear perinuclear halo were observed along the posterior surface of the CS, in proximity to the entrance of the oblique vein of Marshall. In addition, the media revealed masses of sinus nodal-like cells ( $\mathrm{P}$ cells) with much interposed connective tissue. This group of P-like cells demonstrated a typical pallid appearance similar to primitive myocardial cells (Rossi et al., 1990). It is the author's hypothesis that this group of cells represents a true nodal structure, otherwise stated, the "Coronary Sinus Node".

The striated myocardium of the CS was covered by epicardium on its posterior surface. There were numerous groups of ganglionic neurons, observed just beneath the epicardium of the CS.

At the level of the A-V sulcus, the anterior surface of the CS is separated from the atrial and ventricular myocardium by connective and adipose tissue, and is therefore not an intramural structure.

\section{DISCUSSION}

Gray's Anatomy describes, "the coronary sinus as a wide venous channel, about $2.25 \mathrm{~cm}$ in length, situated in the posterior part of the atrioventricular sulcus of the heart, usually covered by muscular fibers from the left atrium".

Consequently, most authors considered the CS to be a segment of the cardiac venous system located in the left posterior atrioventricular sulcus, beginning at the entrance of the oblique vein of Marshall, and ending at an ostium in the right atrium. This traditional belief is erroneous based upon the anatomical and histological findings relative to the $\mathrm{CS}$ described in this communication.

The CS demonstrates an endocardium, myocardium and epicardium, and is anatomically discrete from the other four cardiac chambers.
When the lumen of the CS is widely dissected along its longitudinal axis, assisted by gross optical magnification, the inner surface conforms more to atrial myocardium than to the endothelium of a typical vein. The small crests or pectinate muscles are anatomically reminiscent of the right atrium.

The medial layer of the CS, having no smooth muscle, instead contains at least a thin layer of the striated myocardial fibers orientated along its long axis, forming a delicate network of true muscular syncytium.

The striated muscle fibers that form the body of the CS musculature have endocardium on their inner surface, epicardium on their external surface, and bear no anatomic relationship to the left atrium.

The CS in the left atrioventricular sulcus is clearly separated on its anterior surface from the left atrial and ventricular muscle by an adipose-cellular tissue complex.

It is important to stress the fact that the CS at the level of the A-V sulcus, clearly is not intramural, and its striated myocardial muscle is integrated into the CS and not into the left atrium. Coakley et al., in various animal species and in three human hearts, found that some of the muscle fibers related to the $\mathrm{CS}$ and the oblique vein, resemble fibers of the sinus and $\mathrm{A}-\mathrm{V}$ nodes. The presence of Purkinje-like cells coupled with the finding of node-like P cells lead the authors to postulate the presence of a CS node having perhaps all of the known properties of automaticity seen in A-V nodal or sinus nodal tissue. This coronary sinus node could be a dormant coronary sinus node bearing the same relationship to the sinus node as the $\mathrm{A}-\mathrm{V}$ node, i.e., having slower intrinsic automaticity. It may be the site of origin of so called "coronary sinus rhythm".

Finally, and in addition to the myocardial muscle connections between the CS and the left atrial musculature described by others (Chauvin et al. 2000; Coakley et al.; Keith; Liotta; Mohl, 2002; Ortale et al., 2001; Silver et al., 1988 and von Ludinghausen et al.), the authors identified a herein undescribed discrete muscular bundle (atrio-coronary sinus bundle) linking the base of the left atrial appendage to the myocardial muscle on the superior surface of the CS.

Bachmann (1916) postulated that the anterior interatrial band was the primary connection between the right and left atrium. This anterior interatrial band ("Bachmann's Bundle") extends from the junction of the superior vena cava and the right atrial appendage transversely to the anterior wall of the left atrium ending at the base of the left atrial appendage. 
The authors postulate that Bachmann's bundle is continuous anatomically and electrically with the myocardial muscular bundle described herein (atriocoronary sinus bundle), that links the base of the left atrial appendage to the myocardial musculature of the CS.

Therefore, the Bachmann's bundle, from the left atrium through the atrio-coronary sinus bundle and the striated musculature of the CS, close an conductive circuit: right atrium a left atrium a CS a right atrium. This circuit may represent a pathway of abnormal conduction responsible for many atrial reentry arrhythmias.

In conclusion, despite a traditional anatomic literature depicting the CS as the "great cardiac vein", the authors present gross and microscopic evidence that this structure is indeed not a vein at all, but a true small cardiac chamber. Hence, the previous allusions to CS musculature being part of the left atrium, or beliefs that the CS is no more than an intramuscular vein are, in our view, erroneous anatomic misconceptions.

Clinical implications:Understanding of the anatomic and physiologic bases of the atrial arrhythmias remains the cornerstone of successful therapy. The generation of some atrial arrhythmias may relate to the spiral sheath of myocardium surrounding the CS and its connections to the right and left atria. The muscle sheath may represent a remnant of the sinus venosus (Gerlis et al., 1985). In electrophysiological studies performed in canine hearts, Antz et al. showed that the CS musculature is electrically connected to the right and left atrium. They postulate that the electrical activity of the CS musculature and its connections with the right and left atria may have implication for the generation of many atrial arrhythmias (Antz et al.).

Recently Farah et al., (2003) demonstrated additional evidence of electric as well as anatomic connections between the left side of the CS and the left atrium.

D'Cruz et al., (1999) described an apical two chamber echo study in patients with sinus rhythm wherein the CS narrows significantly during atrial contraction and widens to a maximum caliber during ventricular systole. This CS narrowing was absent in patients with atrial fibrillation and they concluded that atrial contraction is necessary for CS narrowing.

Our observations using selective cineangiograms and intravascular ultrasound of the CS in patients with normal sinus rhythm demonstrated additional evidence of narrowing of the CS during atrial contraction (Fig. 6).
In the last few years, electrophysiologists have been exploring and mapping the CS.

Kasai et al., (2001) in patients with supraventricular arrhythmias, documented evidence of delayed conduction and a propensity to conduction block within the CS.

Katritsis et al., (2002) also found delayed conduction in the CS and associated these findings with an increased proclivity to atrial arrhythmias. Volkmer et al. ablated a focal atrial tachycardia originating within the CS.

Macle et al., (2002) recently identified epicardial potentials at the distal CS, probably representing accessory pathway activity.

In an editorial, Eckardt, (2002), referring to this study, discussed mapping of the CS to seek out evidence of intrinsic automaticity, which he believes is related to an accessory pathway such as the bundle of the ligament of Marshall. It is possible that the automaticity of the CS in some patients is related to the presence of the CS node as herein described. Mapping data from studies of the human CS may improve our understanding of the reentrant circuits involved in certain atrial arrhythmias: they may explain also why some posteroseptal or left posterior accessory pathway has yet to be found by standard mapping techniques (Sun et al., 2002). It is possible that an aberrant atrial focus in some patients arises from the CS musculature and/or its connections to the left and right atrium. Catheter ablation in or around the CS may eliminate some cases of sustained atrial activity, heretofore refractory to radiofrequency treatment.

Conclusions:Magnification assisted, gross anatomic dissection and histological study of the coronary sinus, suggests this structure to be an independent, albeit diminutive, cardiac chamber with a mural structure similar to atrial myocardium. We also found that all the affluent veins that arrive to the CS are cover by striated muscle related to the CS, like the pulmonary veins arriving to the left atrium.

An intracameral conduction system with a coronary sinus node and Purkinje-type fibers are also present and may be targets for study and ablation, in the future therapy of atrial arrhythmias.

ACKNOWLEDGMENTS: The authors acknowledge Ximena Manglano, M.D. and Gustavo Abuin, M.D. for their scientific and technical collaboration; the Fundación H.A. Barceló for its scientific support; and Julio C. Argentieri, M.D.; Hector de la Fuente and Amalia Coronado for their invaluable technical assistance. 
BARCELÓ, A.; DE LA FUENTE, L. M. \& STERTZER, S. H. Revisión anatómica e histológica del seno coronario. Int. J. Morphol., 22(4):331-338, 2004.

RESUMEN: El seno coronario (SC), tradicionalmente considerado simplemente una gran vena cardiaca, es mostrado, de acuerdo a sus características anatómicas, como una verdadera cámara cardiaca: endocardio, miocardio estriado, epicardio y un sistema de conducción específico.

Fueron disecados 14 corazones humanos, utilizando aumento óptico. Imágenes de alta resolución fueron obtenidas con una cámara digital. Los datos fueron analizados con softwares especializados.

Hallazgos macroscópicos: 1) Existencia de músculo cardiaco estriado formando la pared del SC sobre su circunferencia, 2) Conecciones musculares atriales-SC. 3) Fascículos musculares atrio-senocoronarios no descritos. Dos tractos musculares conectan el SC al atrio derecho $(\mathrm{AD})$, (uno antero-superior o septal, y otro postero-inferior o atrial) fueron también descubiertos. Hallazgos miscroscópicos: 1) Fibras miocárdicas estriadas en la capa media. 2) Un grupo de células similares a las células $P$ del nodo sinoatrial, además de un amplio número de células tipo Purkinje. Grupos numerosos de neuronas ganglionares fueron identificados en el epicardio.

En relación a la función de transporte venoso, el SC es una discreta estructura, en forma de cámara, situada en el surco posterior izquierdo (surco atrioventricular) y no en la pared del atrio o del ventrículo. Los hallazgos sugieren que el fascículo de Bachmann's , el fascículo atrio-senocoronario, la musculatura del seno coronario y el atrio derecho pueden ser, todos, parte del sistema de conducción cardiaco y contribuir a la génesis de las arritmias cardiacas. Por lo tanto el SC es una pequeña cámara cardiaca que se une a las otras cuatro cámaras a nivel de la cruz cardiaca.

PALABRAS CLAVE: 1. Anatomía cardiaca; 2. Seno coronario: 3. Arritmias; 4. Sistema de conducción.

\section{REFERENCES}

Antz, M.; Otomo, K.; Arruda, M. \& et al. Electrical conduction between the right atrium and the left atrium via the musculature of the coronary sinus. Circulation 98:1790-5, 1998.

Bachmann, G. Interauricular time interval. Am. J. Physiol., 41:309-38, 1916.

Bashour, T. T.; Banks, T. \& Cheng, T. O. Retrieval of lost catheters by a myocardial biopsy catheter device. Chest., 66(4):395-6, 1974.

Chauvin, M.; Shah, D. C.; Haissaguerre, M. \& et al. The anatomic basis of connections between the coronary sinus musculature and the left atrium in humans. Circulation, 101:647-52, 2000.

Coakley, J. B. \& Summerfield, K. T. Cardiac muscle relations of the coronary sinus, the oblique vein of the left atrium and the left precaval vein in mammals. $J$. Anat., 93: (1):30-5, 1946.

Cosío, F. G.; López-Gil, M.; Goicolea, A.; Barroso, J. L. \& Karoni, A. radiofrequency modification of the critical isthmus in atrial flutter. Eur. Heart J., 12(Supl):369, 1991.
D’Cruz, I. A.; Johns, C. \& Shala, M. B. Dynamic Cyclic Changes in Coronary Sinus Caliber in Patients With and Without Congestive Heart Failure. Am. J. Cardiol., 83, 1999.

Eckardt, L. Automaticity in the Coronary Sinus. J. Cardiovasc. Electrophysiol., 13:288-9, 2002.

Farah, S.; Spodick, D. H. Effect of interatrial block on coronary sinus contraction. Am. J. Cardiol., 91(8): 2003.

Forssman, W. Die Sondierung des rechten Herzens. Klin Wochenschr, 8:2085-90, 1929.

Gerlis LM, Davies MJ, Boyle R,et al: Pre-excitation due to accessory sinoventricular connections associated with coronary sinus aneurysms. A report of two cases. Br. Heart. J., 53:314-22, 1985.

Gray's Anatomy. Lea \& Febiger. Atrioventricular sulcus, 1985. p 798

Gruentzig, A. R. Percutaneous trasluminal coronary angioplasty. Sem. Roentgenol., 16(2):152-3, 1981. 
Kasai, A.; Anselme, F. \& Saoudi, N. Myocardial connections between left atrial myocardium and coronary sinus musculature in man. J. Cardiovasc. Electrophysiol., 12:981-985, 2001.

Katritsis, D.; Ioannidis, J. P. A.; Giazitzoglou, E. et al. Conduction Delay Within the Coronary Sinus in Humans: Implications for Atrial Arrhythmias. J. Cardiovasc. Electrophysiol., 13:859-862, 2002.

Keith, A. The anatomy of the valvular mechanism round the venous orifices. J. Anat., 37, Proc. II-XXXVI, 1902.

Liotta, S. Contribución al estudio anatómico funcional del seno coronario (Sinus Coronarius)" Tesis Doctoral. Universidad Nacional de Córdoba - Facultad de Ciencias Médicas, 1971.

Macle, L.; Shah, D. C.; Jais, P. et al. Accessory pathway automaticity after radio frequency ablation. J Cardiovasc Electrophysiol 2002: 13: 285-287.

Mohl, W. Anatomy and Pathophysiology of the coronary venous circulation. Society of Coronary Sinus Interventions. Editor W. Mohl, Austria, 2002.

Ortale, J. R.; Gabriel, E. A.; Iost, C. et al. The anatomy of the coronary sinus and its tributaries. Surg. Radiol. Anat., 23:15-21, 2001.

Rossi, L. \& Matturri, L. Clinico-pathological Approach to Cardiac Arrhythmias. A Color Atlas. Torino, Centro Scientifico Torinense Editore, 1990.

Silver, M. A. \& Rowley, N. E. The functional anatomy of the human coronary sinus. Am. Heart J., 115:1080, 1998.
Sones, F. M. Cine-cardio-angiography. Pediatr. Clin. North A., 5(4):945-79, 1958

Sun, Y.; Arruda, M.; Otomo, K. \& et al. Coronary sinusventricular Accessory Connections producing posteroseptal and left posterior accessory pathways. Incidence and Electrophysiological identification. Circulation, 106:1362-7, 2002.

Volkmer, M.; Antz, M.; Hebe, J. et al. Focal atrial tachycardia originating from the musculature of the coronary sinus. J. Cardiovasc Electrophysiol., 13:68-71, 2002.

von Ludinghausen, M.; Ohmachi, N. \& Boot, C. Myocardial coverage of the coronary sinus and related veins. Clin. Anat., 5:1-15, 1992.

Correspondence to:

Prof. Dr. Adrián Barcelo.

Fundación H.A. Barceló

Laboratorio de Cardioanatomía.

Larrea 770

Buenos Aires, 1030

ARGEX TIN $\mathcal{A}$

Phone and Fax: 5411-4962-2490.

E-mail: aj6arcelo@elsitio.net

Recibido : 06-04-2004

Aceptado: 24-10-2004 